\section{BULLETIN OF THE BRITISH MUSEUM (NATURAL HISTORY)}

Published in five series; ENTOMOLOGY, ZOOLOGY, BOTANY, GEOLOGY (incorporating MINERALOGY) \& HISTORICAL.

Medium length research papers and reports on the Museum's collections. Available on subscription or as separate parts, each complete in itself.

\section{LATEST TITLES}

ENTOMOLOGY SERIES Volume 43

No. 1. A revision of the genus

Usambilla Sjöstedt (Orthoptera:

Acridoidea) and its allies. N.D. Jago

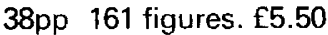

ZOOLOGY SERIES Volume 41 No.

1. Anatomy and phylogeny of the

Chinese Major Carps

Ctenopharyngodon Steind., 1866

and Hypophthalmichthys Blkr.

1860. G. Howes. 52pp, 34 figures. £7.75

BOTANY SERIES Volume 9 No. 1. The lichenicolous Coelomycetes.

D.L. Hawksworth. 98pp, 36 figures. $£ 13.25$

GEOLOGY SERIES Volume 35 No.

2. The fossil alga Girvanella

Nicholson \& Etheridge. H.M.C.

Danielli. 28pp, 8 figures, 3 tables.

$£ 4.20$

\section{HISTORICAL SERIES Volume 9}

(complete in one part). The journal

of Peter Good gardener on Matthew Flinders voyage to Terra Australis 1801-03. Edited with an introduction by P.I. Edwards. 213pp, frontispiece, 8 plates, facsimiles of seed lists etc. £24.00

\section{Publications Sales,}

British Museum

(Natural History),

Cromwell Road,

London SW7 5BD.

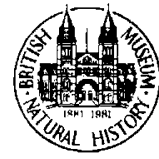

for a sociobiological journal; indeed the editors themselves admit to a difficulty in finding a satisfactory title. This is easily understood since they see their subject as "the relationship between biological and social phenomena on the level of theory", which is commendably or eccentrically broad, depending on one's point of view. Alongside the expected articles on dominance, the pair-bond, altruism and selfishness, concealed ovulation and so forth are a host of others that hardly fit conventional definitions ò sociobiology - post-industrial economics, physics as a model for medicine, recombinant DNA, time, French literature and history, urban growth, the arms race and even the White House tapes. It is hard to assess all these contributions, but to me they seem very uneven. What will be at least as influential,

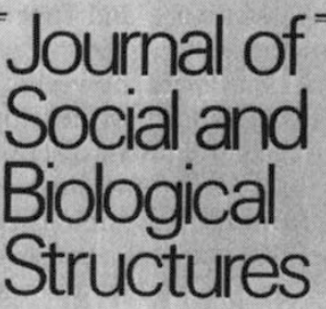

however, in attracting or deterring subscribers and contributors, will be the sheer breadth of the journal's scope, combined with its concentration on theory.

Ethology and Sociobiology (ES) is in several ways a different proposition. In subject matter, it is far more homogeneous, being largely restricted to ethology and sociobiology as conventionally understood - communication, courtship, kin selection, concealed ovulation again, and so on - and with the important difference that empirical studies of these topics are given as much prominence as theoretical discussion. The quality, too, is more homogeneous: the general standard is quite impressive, especially given the immaturity of the field. It is also, incidentally, more attractively produced; and it generally publishes papers within six months of revision (comparable dates are not given in JSBS).

Clearly, some institutions will wish to subscribe to both JSBS and ES, as each has something to offer. But for those, whether institutions or individuals, who must choose one of them, I have no hesitation in recommending $\mathrm{ES}$. Its range may seem less adventurous, but its contents are no less stimulating; and its more coherent intellectual focus makes it distinctly the more promising investment for those whose research, teaching or sheer interest brings them to read about modern biological perspectives on human social behaviour.

Robert Attenborough is a Lecturer in Biological Anthropology in the Department of Prehistory and Anthropology, Australian National University, Canberra.

\section{Talking of Primates}

\section{Alison Jolly}

International Journal of Primatology. Managing editors G.A. Doyle and $\mathbf{M}$. Cartmill. 4/yr. (Plenum.) \$40 US, \$46 elsewhere.

THE editors of the International Journal of Primatology (IJP), the new journal of the International Primate Society, state their aims as the production of a refereed journal devoted to fundamental rather than applied research, with short, long and review papers on all aspects of primatology. To judge from their efforts thus far, they seem set for success.

The IJP does not break new ground, however, and will face competition from both new and established journals. Its coverage coincides with that of Primates and Folia Primatologia and probably with the new American Journal of Primatology (published by Alan R. Liss; the first number appeared earlier this year). However the amount of primate research has grown so much that it needs extra outlets, in part to minimize delays in publication of papers. The time lag from receipt of articles to publication for the IJP was 12 months for the first issue and averaged 8 months thereafter $(7$ months for articles needing no revision and 3 from receipt of revisions). In 1980, Primates averaged 12 months from receipt of a paper, and 8 from editorial acceptance. Folia is now down to " $6-7$ months, and probably 5 next year', according to Dr Biegert, the editor.

The IJP so far includes field research, laboratory studies of behaviour and taxonomic comparisons at anatomical, chromosomal and biochemical levels, as well as physiology and palaeontology. The quality of articles is at least as high as in the established journals. In addition, for subscribers, it gives value for money, at 5-11 cents per page, compared to about 9 cents for Primates and 11-22 cents for Folia. In short, any library dealing in primatology should add the IJP to its list.

A more interesting question is whether primatology itself is a credible field of study. Why publish yet another journal devoted to one order of mammals, instead of letting ecologists talk to other ecologists and chromosome types among themselves? Primatology's egocentric fascination helps counter the tunnel vision of our respective disciplines, which sometimes resemble the blind men describing the elephant. The IJP keeps contact between people who ask whether baboons, like humans, need two $\mathrm{X}$-chromosomes to develop ovaries, and those who ask why the spectral tarsier, like the agile gibbon, is territorial, monogamous and sings.

Alison Jolly is a Research Associate in the School of Biological Sciences, University of Sussex. 